\title{
Copper use in organic agriculture in twelve European countries
}

Lucius Tamm 1, \$, Barbara Thuerig 1,\$, Stoilko Apostolov 2, Hugh Blogg 3, Esmeralda Borgo 4, Paola Elisa Corneo 5,6, Susanne Fittje 7, Michelangelo de Palma 8, Adam Donko 9, Catherine Experton 10, Évelyne Alcázar Marín 11, Ángela Morell Pérez 11, llaria Pertot 5,6, Anton Rasmussen 12, Håvard Steinshamn 13, Airi Vetemaa ${ }^{14}$, Helga Willer ', Joelle Herforth-Rahmé I

\$ These authors share first authorship

I Research Institute of Organic Agriculture FiBL, Ackerstrasse I I3, 5070 Frick, Switzerland

2 FOA Bioselena, 36, Vasil Karaivanov str., 4300 Karlovo, Bulgaria

3 Soil Association, Marlborough St, South Plaza, BSI 3NX BRISTOL, United Kingdom

4 Bioforum, Lamorinierestraat 16I, 2018 Antwerpen, Belgium

5 FEM Fondazione Edmund Mach, via Mach I, S. Michele all'Adige, 38010 TN, Italy

6 University of Trento C3A Center Agriculture Food Environment, Via Calepina, 14, 38122 Trento TN, Italy

7 Naturland, Kleinhaldener Weg I, 82I66 München, Germany

8 FederBio, Via Livenza 6, 00198 Roma, Italy

9 ÖMKI, Melczer Utca 47, I I 74 Budapest, Hungary

I0 ITAB, Rue de Bercy 149, 75595 Paris, France

I I ECOVALIA, Edificio Insur, Avenida Diego Martínez Barrio, n 10, planta I módulo 12, 41013 - Sevilla, Spain

12 OKOLOGISK LANDSFORENING, Silkeborgvej 260, 8230 Abyhoj, Denmark

13 NIBIO, Hoegskoleveien 7, I430 Aas, Norway I 3 EOFF, Kungla IA, 50403 Tartu, Estonia

\section{Key words:}

Copper-based plant protection products, copper fungicides, organic agriculture, survey, grapevine, olives, nuts, potatoes

\section{Acknowledgements}


This survey was performed within the EU Project RELACS - 'Replacement of Contentious Inputs in Organic Farming Systems' (RELACS) with funding from the European Union's Horizon 2020 research and innovation programme under grant agreement No 773431 .

We gratefully acknowledge Bernhard Speiser (FiBL) for critically reviewing the manuscript.

\section{Summary (150-250 words)}

Reduction of copper-based fungicides with the final aim of phasing out has a high priority in European policy as well as in organic agriculture. Our survey aims at providing an overview of the current use of copper-based plant protection products in European organic agriculture and the need for alternatives to allow policy makers to develop strategies for a complete phasing out. Due to a lack of centralized databases on pesticide use, our survey combines expert knowledge on permitted and real copper use per crop and country with statistics on organic area.

In the 12 surveyed countries, covering together $83 \%$ of the European organically managed horticultural area, we calculated approximately $3258 \mathrm{t}$ copper metal per year are consumed by organic agriculture, equalling to $53 \%$ of the permitted annual dosage. This amount is split between olives (1263 t $\left.\mathrm{y}^{-1}, 39 \%\right)$, grapevine (990t $\left.\mathrm{y}^{-1}, 30 \%\right)$, and almonds (317 t $\left.\mathrm{y}^{-1}, 10 \%\right)$, followed by other crops with much smaller annual uses $\left(<80 t y^{-1}\right)$. Potato, usually considered a highly demanding plant for copper inputs, only uses $39 t y^{-1}$ of copper per year. In $56 \%$ of the allowed cases (countries $x$ crops), farmers use less than half of the allowed amount, and in $27 \%$ less than a quarter, with some variability between countries. Considering the large volumes of copper used annually, replacement of copper seems only feasible if all preventive strategies from the crop protection pyramid are fully implemented and several affordable alternative plant protection products are successfully brought to the market. 


\section{Introduction}

The use of copper-based fungicides has a long tradition, dating back to the late 19th century when Alexis Millardet accidentally discovered the efficacy of neutralised copper sulfate to reduce grapevine downy mildew (Ayres, 2004). This discovery revolutionized agricultural production, by providing the first effective tool to control various phytopathogens. Although many fungicidal active substances have been discovered in the meantime, copper-based plant protection products are still widely used in organic and conventional agriculture for a number of reasons. Copper has a very wide spectrum of activity, including bacteria, oomycetes, ascomycetes, and basidiomycetes, and it is very effective against diseases, such as downy mildew of grape and late blight of potato, which are of world-wide importance. Copper is also a useful tool against secondary or minor diseases and widely used in minor crops such as vegetables or speciality fruit (Speiser et al., 2018). Other favourable agronomical properties of copper include high efficacy under conditions of rain and low temperatures, moderate phytotoxicity, its multisite mechanism of action that minimises the risk of development of resistant pathogen strains and the relatively low acute toxicity for terrestrial vertebrates (Speiser et al., 2018, Lamichhane et al., 2018). Besides its use as a fungicide, copper is also authorized as micro-nutrient leaf fertilizer and widely used in feed additives (Panagos et al., 2018). Micronutrient fertilizers may contain copper under the form of copper salt, copper oxide, copper hydroxide, copper chelate, copper oxychloride, as a copper complex, or as mixtures of components (i. e. Copper-based fertilizer, Copper fertilizer solution). Most of the copper used as a feed additive ends up in the manure. This is considered a substantial source of copper input in arable crops and fodder production, especially when pig slurry and manures from conventional farms are imported in organic farms (Panagos et al., 20l8), but it has no relevance in the control of soil-borne pathogens. Being an element having scarce mobility in soil, repeated foliar applications of copper-based plant protection products lead to copper accumulation in the soils and to potentially consequent negative impacts on soil fertility (negative effects e.g. reviewed by La Torre et al. (20I8)), even though studies put the negative effects in perspective (e.g. reviewed by Karimi et al. (202I)).

The maximum copper quantity allowed in plant protection has been successively restricted in Europe over the last decades, and is currently limited by the European plant protection legislation to a maximum of $28 \mathrm{~kg}$ per ha over a period of 7 years (status 202I) (regulation (EU) 2018/198I (European Commission, 2018)). The final objective would be to phase copper out, as it is included in the list of 'candidates for substitution' in the EU (Part E of the Annex to Regulation 540/20II (European Commission, 202lb) ) and Switzerland (Aktionsplan Pflanzenschutzmittel, www.BLW.admin.ch, last edited in July 202I). In organic farming, copper-based plant protection products and fertilizers are explicitly allowed according to the European Commission implementing Regulation (EU) No 202 I/I I 65 (European Commission, 202 la). In addition to European legislation, EU Member States (MS) can further restrict the quantity or authorize only specific uses. For example, in five out of $27 \mathrm{EU}$ member states (Denmark, Sweden, Finland, The Netherlands and Estonia), copper is not registered as a plant 
protection product. Furthermore, in a range of countries, private 'label organizations' self-restrict copper use beyond the legal requirements. As a consequence of overlapping EU regulations and of differences in nationally authorised plant protection products and practices at different levels, it is difficult to get a precise overview of permitted uses (i.e. in which crops against which pathogens in which maximum quantity).

There is a substantial difference between the maximum quantity of copper permitted for a specific use (crop/disease) and its real use, as already highlighted in Switzerland, France and Germany (Speiser et al., 2015, Kühne et al., 2017, Andrivon \& Savini, 2018). For example, a survey in Switzerland found that organic farmers use on average between $3 \%$ and $80 \%$ of the maximum permitted amount of copper depending on the crop, indicating a high awareness among farmers of the need to reduce copper use (Speiser et al., 2015). Katsoulas et al. (2020) report considerable variability in copper use between regions and/or producers in European organic farming, depending e.g. on climatic conditions, cultivars or production systems, and indicate that annual copper limits were not always respected.

Even though various tools and strategies to reduce copper-based plant protection products, such as resistant varieties, cultural measures, decision support systems and alternative plant protection products are available for farmers (Finckh et al., 2015), completely abandoning copper fungicides would lead to high yield losses in many crops at the time being (Kühne et al., 20l7). To develop strategies and pathways for a complete phasing out of copper-based plant protection products, policy makers need information on the current dependency on copper-based plant protection products, the implementation of alternative strategies, and the need for copper alternatives in European organic crop production. Our survey aimed at (i) giving an overview on the current legal status of copper uses in organic farming in different European countries, (ii) the identification of crops in which the major amounts of copper are used, and (iii) an estimate of the total amounts of copper used in European organic crop protection. The survey is based on knowledge of national experts (researchers, extension specialists and experts from farmer associations) from 12 European countries, including Belgium, Bulgaria, Denmark, Estonia, France, Germany, Hungary, Italy, Norway, Spain, Switzerland, and the UK. 


\section{Methods}

The present survey on the theoretically allowed and real use of copper-based plant protection products in European organic agriculture includes 12 European countries, covering all European agroclimatic zones as defined by the European Plant Protection Organisation (EPPO): Mediterranean (Italy, Spain, part of France), Maritime (Belgium, part of France, Germany, Switzerland, United Kingdom, Denmark, part of Norway), North East (Estovia, part of Norway), and Central (Bulgaria, Hungary) zone (Bouma, 2005).

The overall organically managed area and the organically managed area per crop for each country were obtained from Statistics.FiBL.org, which gives access to the data collected annually by the Research Institute of Organic Agriculture (FiBL) and partners (also published annually by FiBL and IFOAM Organics International in the yearbook 'The World of Organic Agriculture' (Willer \& Lernoud, 2019)). Data for 2017 were used for this survey. Only selected crops were listed and unspecific categories were excluded. The sum of the area for the selected crops does therefore not correspond with the total organic farmland for a country.

The European pesticide database was consulted for approval of copper compounds as active substances in the involved countries (European Commission, 202lc) and amended by information on emergency approvals at national level. National databases (e.g. listed by the European and Mediterranean Plant Protection Organisation EPPO (202I)) were checked for permission of copper-based plant protection products and permitted uses (crops, dosages in $\mathrm{kg} \mathrm{ha}^{-1}$ ). This information was further verified and supplemented by national experts from research institutes, farmers associations or extension services participating in the EU project on which this survey is based, or by experts in their network, amounting to 29 involved national experts (Tab.I). This expertise was included to fill knowledge gaps, as plant protection products are also allowed for use by way of emergency registrations (SANCO/I0087/20 I3, (DG SANCO, 20I3)), minor use registrations (OECD, 20I4), or special national instruments such as Off-Label Extension of Authorisation for Minor uses (EAMU)(http://www.eumuda.eu/) and this is not mapped in the EU pesticide database.

For each crop where the use is permitted, real average copper use by organic farmers (in $\mathrm{kg} \mathrm{ha}^{-1}$ ) was estimated by the national experts for each country. A total of II 5 crops or crop categories (according to Statistics.FiBL.org) were evaluated. Out of these 115 crops/crop categories, 5 I were perennial crops/crop categories and 64 annual crops/crop categories. For key crops, a description of the most widely used crop protection strategies, targeted on diseases controlled by copper, was compiled based on knowhow of national experts of relevant countries. Moreover, the immediate potential for further reduction of copper use - which does not compromise yield stability - was assessed (summarized in Table SI, supplementary).

The amount of copper allowed in organic plant protection was calculated for each crop and country as follows: 
Copper $_{\text {allowed }}\left(\mathrm{kg}^{-1}\right)=$ Area (ha) $*$ permitted use $\left(\mathrm{kg} \mathrm{ha}^{-1} \mathrm{y}^{-1}\right)$

The amount of copper really used in organic plant protection was calculated for each crop and country as follows:

Copper $_{\text {used }}\left(\mathrm{kg}^{-1}\right)=$ Area $(\mathrm{ha}) *$ estimated real use $\left(\mathrm{kg} \mathrm{ha}^{-1} \mathrm{y}^{-1}\right)$

The amount of copper really used by organic farmers was put into perspective with the allowed amount for each crop and country as follows:

Copper utilization rate $=\left(\right.$ Copper $\left._{\text {used }}\right) *\left(\text { Copper }_{\text {allowed }}\right)^{-1}$

Pearson correlation coefficient was calculated using the software IBM SPSS Statistics for Windows (IBM Corp. Released 2015. Version 23.0. Armonk, NY: IBM Corp.).

\section{Results}

\section{I Authorized uses of copper in European agriculture}

While copper compounds are approved as active substances for plant protection at EU level (Regulation (EC) No I107/2009 (European Parliament and the Council, 2009)), plant protection products containing copper are registered for the use in individual crops and against individual pathogens at national level, resulting in different copper limits for individual cases (countries $\times$ crop). Our survey shows that copper-based plant protection products are registered in 25 out of 30 European countries (22 EU member states as well as the non-EU countries Norway, Switzerland, and the United Kingdom). In five out of $27 \mathrm{EU}$ member states, copper is not registered as an active substance (Denmark, Sweden, Finland, the Netherlands and Estonia). The copper compounds authorised as active substances in fungicides in the EU are: 'Bordeaux mixture', copper hydroxide, copper oxide, copper oxychloride, and tribasic copper sulphate. However, not every copper compound is registered in each country. Copper hydroxide and oxychloride are both registered in 22 countries, followed by tribasic copper sulphate (16 countries), copper oxide (12 countries) and Bordeaux mixture (ten countries) (Table S2, supplementary).

Different overlapping European and national regulations, the lack of centralized databases and additional self-restrictions beyond the legal requirements by national label organizations make it difficult to get an overview on allowed copper uses (country / crops / pathogens) and the limits that apply. At the international level, Demeter International limits the amount averaged over 7 years to $3 \mathrm{~kg} \mathrm{ha-}^{-1} \mathrm{y}^{-1}$, and recommends a maximum of $500 \mathrm{~g} / \mathrm{ha} / \mathrm{spray}$ (Biodynamic Federation Demeter, 202I). The Demeter International standard allows for exemptions in wine- and hop growing regions with high fungal pressure. In these cases, the respective certifying organisation may grant an exemption for the use of an average amount of up to $4 \mathrm{~kg} \mathrm{ha}^{-1} \mathrm{y}^{-1}$ ear over 5 years for grapes and hops. At national level, associations such as Bio Austria (AT), Bioland (DE), Naturland (DE), Bio Suisse (CH), or PRO-BIO (CZ) defined crop-specific limitations. Copper limits set by private standards are summarized in Tab. 
2, case-specific (i.e. country $x$ crop) limits are summarized in Tab. 3 and 4 and discussed in the next section.

The use of micronutrients fertilizers with copper was not found to be specifically limited in any country. However, some private organic standards restrict their use (Tab. 2). For example, Bio Suisse ( $\mathrm{CH})$ follows the policy not to allow any micronutrient fertilizers containing copper, and Okologist Norge (NO) does not allow copper fertilizers without proof of necessity. In practice, experts agree that this strategy limits leaf fertilizer use in these countries severely. In contrast, leaf fertilizers are indeed allowed and used in organic farming in Denmark and the Netherlands, where the use of copper-based plant protection products is not allowed.

In fertilizers containing the macronutrients $\mathrm{N}, \mathrm{P}, \mathrm{K}, \mathrm{Mg}$ and $\mathrm{Ca}$, copper is considered a contaminant, and maximum levels are defined. Here, the copper $(\mathrm{Cu})$ content in an organic fertiliser must not exceed 300 mg/kg dry matter (Regulation (EU) 2019/1009, (European Parliament and the Council, 2019). Yet, we found that fertilizers do not undergo stringent approval procedures in many European countries, and the full composition is rarely divulged by the manufacturer. Furthermore, leaf fertilizers may contain substances with well-known plant protection properties such as copper, phosphonate or insecticides such as Matrine (Sabatino et al., 2015). Harmonization is intended on European level for the future, as the new Fertiliser Regulation offers optional harmonisation: In order to get the CE marking, the requirements of the new regulation have to be met. For their internal markets, the EU member states will still have the possibility to set specific rules, and it is still possible to recognise products mutually (Regulation (EU) 2019/1009, (European Parliament and the Council, 2019).

Beyond European regulation, an increasing number of organic farmers associations and certifiers have joined forces to develop a harmonized and transparent inputs assessment scheme to facilitate use of high-quality products in organic farming (https://www.inputs.eu/ (Research Insitute of Organic Agriculture FiBL, 202I)). At present, the network publishes input lists for Austria (AT), Croatia (HR), Germany (DE), Italy (IT), The Netherlands (NL), Sweden (SE) and Switzerland (CH).

\subsection{Copper use by European organic farmers}

\subsubsection{Copper use authorization and estimated real use per hectare and year}

This survey in the 12 selected European countries covers 2.9 million hectares of organically managed horticultural (temperate fruits, grapes, olives, nuts, vegetables including potato) and arable crops. Permanent grasslands were not included. The use of copper is permitted on a total 1.55 million hectares. Among the countries included in the survey, Italy, Spain and France represent the largest areas of horticultural crops in organic production in Europe (75\%). Together with the other nine 
countries included in this survey, $83 \%$ of the organically managed European (EU + Switzerland + UK + Norway) horticultural area is covered (Table S3, supplementary).

Copper as a plant protection product is permitted on a wide range of perennial (Tab. 3), as well as on selected vegetable crops (Tab. 4) in the 12 surveyed European countries. In arable crops (Tab. 4), copper is only used on potato as a plant protection product, but it is sometimes used as a leaf fertilizer without expectations regarding disease control. The number of uses allowed per country depends directly on whether the climate is suitable for certain crops. In Italy, Spain and France, copper is allowed in more than 40 crops/crop categories (Tab. 3 and 4). In the southern central European countries such as Germany or Switzerland, the use is permitted on approximately 20 crops, whereas in the northern central European countries, five to ten uses are registered. In the examined countries, copper is mainly allowed on apple and grapevine (12 countries), pear (eleven), potato and plums (eight each), and cherries and strawberries (seven each) (Tab. 3 and 4). Some crops such as olives or almonds are only grown in few of the surveyed countries, and thus, consequently, only few allowed uses are registered. Permitted amounts of copper vary between $1.2 \mathrm{~kg} \mathrm{ha}^{-1}$ and $4 \mathrm{~kg} \mathrm{ha}^{-1}$, but are between 3 and $4 \mathrm{~kg} \mathrm{ha}^{-1}$ $\mathrm{y}^{-1}$ in most cases (crops $x$ country). In Belgium, copper limits of $2 \mathrm{~kg} \mathrm{ha}^{-1}$ apply for all permitted uses except for apple and pears $\left(2.6 \mathrm{~kg} \mathrm{ha}^{-1}\right)$ and potatoes $\left(4 \mathrm{~kg} \mathrm{ha}^{-1} \mathrm{y}^{-1}\right)$, while in Italy and France, in all permitted cases $4 \mathrm{~kg} \mathrm{ha}^{-1}$ are allowed. In other countries (e.g. Switzerland, Germany, Spain), permitted amounts vary depending on the crop.

Organic farmers use between 0 and $100 \%$ of the maximum allowed amount of copper depending on the crop and/or country, i.e. copper utilization rates $\left(\left(\right.\right.$ copper $\left.\left._{\text {used }}\right) *\left(\text { copper }_{\text {allowed }}\right)^{-1}\right)$ ranged between 0 and I. Over all surveyed countries, copper utilization rates were $<0.25$ in $27 \%$ of the allowed cases (crops $\times$ country), $<0.5$ in $56 \%$, and $>0.75$ in $27 \%$ of the allowed cases (Tab. 5), with some variability between countries. The UK showed the highest percentage of cases with utilization rates $<0.5$ (94\%), followed by Germany (70\% of cases), Switzerland (67\%), Spain (62\%), France (61\%), Bulgaria (47\%) and Italy (4I\%). The relatively high percentage of cases with high copper utilization rates in Belgium, Norway and Hungary has to be put in perspective with low maximum permitted copper quantities (2 $\mathrm{kg} \mathrm{ha}^{-1} \mathrm{y}^{-1}$ in Belgium, $3 \mathrm{~kg} \mathrm{ha-1} \mathrm{y}^{-1}$ in Norway and Hungary) in most crops and, for Norway, with very limited number of permitted uses ( 3 crops). Copper utilization rates vary between crops (Tab. 3 and 4). For example, in apple, 3-4 $\mathrm{kg} \mathrm{ha}^{-1} \mathrm{y}^{-1}$ are permitted in Germany, Spain, Switzerland or the UK, but on average only I-2 kg are used. In other crops, limits are often fully exploited, even though differences between countries may exist. For example, in grapevine, the maximum allowed amount of copper is used in five out of the eight countries which allow its use.

\subsubsection{Annual copper use}

In order to put copper use in organic farming into perspective with its impact on the economy and the environment, copper consumption was calculated for each case (crop $\times$ country) by multiplying the amount of copper allowed/used $\left(\mathrm{kg} \mathrm{ha}^{-1}\right)$ by the corresponding cultivated area (ha). Overall, organic 
farmers in the 12 surveyed countries made use of about $53 \%$ of the total authorised amount of copper, equalling to approximately 3'300 t copper metal per year (Tab. 6).

Among the countries included in this survey, the highest amounts of copper per year were used in Italy (app. 1550 t), Spain (app. II 100 t) and France (app. 500 t), followed by Bulgaria (67 t), Germany (42 t), and Hungary (22 $\mathrm{t}$ ). Copper use was highly correlated to the organically managed area on which copper use is allowed ( $R^{2}=0.94 \mathrm{I}, \mathrm{P}<0.0 \mathrm{I}$, Pearson), which obviously depends on the size of the country, the share of organically managed land, the cultivated crops and copper authorizations in these crops.

In the 12 surveyed countries, olive production with estimated $1263 \mathrm{t}$, grapevine production with 990 $t$, and almonds with $317 \mathrm{t}$ account together for nearly $80 \%$ of the estimated annual copper use (Tab. 7). Nuts (no details), apples, vegetables (fruit), oranges, hazelnuts, vegetables (no details), potatoes, and barley (copper used as fertilizer) each use between 40 and $80 \mathrm{t}$ per year, accounting together for $14 \%$ of total copper consumption. Protein crops, lemons and lime, cherries, citrus (no detail), kiwis, brassicas, wheat (copper used as fertilizer), apricots, plums, pears and peaches each use between 10 and $25 \mathrm{t}$ per year, accounting together for $6 \%$ of total annual copper use. All other crops/categories use less than 10 t per year. Aggregating crops into crop categories (Tab. 8), "vegetable crops" (aggregating "vegetables fruit" and "vegetables no details") rank $4^{\text {th }}$ ( $\left.106 \mathrm{t} \mathrm{y}^{-1}, 3.3 \%\right)$ after the top three categories "olives" (I 263 t y-1, 38.8\%) ,"grapes" (990 t y-I, 30.4\%), and "nuts" (aggregating "almonds", "hazelnuts", "nuts no details", "walnuts")(459 t $\left.y^{-1}, 14 \%\right)$. "Citrus fruit" rank $5^{\text {th }}$ (102 t $\left.y^{-1}, 3.1 \%\right)$, before "pome fruit" (78 t $\left.\mathrm{y}^{-1}, 2.4 \%\right)$, "cereals" (72 t $\mathrm{y}^{-1}, 2.2 \%$, fertilizer use), and "stone fruit" (67 t $\left.\mathrm{y}^{-1}, 2.1 \%\right)$ in the 12 surveyed countries (Tab. 8). Potatoes only ranked 9th with $39 \mathrm{t} \mathrm{y}^{-1}$ (I.2\%).

The ranking of relative importance differs substantially between countries. In Belgium, where application is allowed in seven crops, potato accounts for $78 \%$ of copper consumption, followed by apple (13\%) and pears (5\%) (Tab. 8). In Bulgaria, where 14 uses are permitted, nuts and grapevine use $69 \%$ of the total quantity, followed by cherries (9\%). In France, grapevine is where the most important use is made (68\%), followed by nuts ( $11 \%$ ), vegetables $(9 \%)$, apple $(7 \%)$ and potato $(2.5 \%)$ with much smaller quantities. In Germany, copper use is relatively equally distributed between grapevine (40\%), potato $(34 \%)$ and apple (19\%). In Hungary, copper is preferably used on apples (37\%), nuts $(28 \%)$ and grapes (23\%). In Italy, an extraordinary wide range of uses is permitted. Olives (45\%) and grapevine (27\%) alone, use up $72 \%$ of total copper, followed by nuts and almonds ( $8 \%$ ), citrus fruits (aggregating "lemons and limes", “oranges", "citrus no details")(5.6\%), and vegetables (2.6\%). Quite remarkably, the amount of copper used on barley and wheat (together 2.5\%) as a fertilizer appears much higher than the amount used as a plant protection product on many important crops such as apples, cherries, apricots, peaches, pears and plums (all $<1 \%$ ). The amount of copper used in Norway with $0.5 \mathrm{t} \mathrm{y}^{-1}$ is minimal in comparison to other countries and concentrates on apples (97\%) and pears (3\%). In Spain, the largest amounts of copper are used in olives (5I\%), almonds (23\%) and grapes (20\%), together accounting for $94 \%$ of the copper used. As in Italy, the use as a fertilizer in barley with $3 \%$ is higher 
than in plant protection on other crops such as vegetables, oranges, apples and nectarines (together below 2\%). In Switzerland, copper use concentrates on grapevine (4I\%) and potato (32\%), followed by vegetable $(9 \%)$, stone fruit $(6 \%)$, berries $(5 \%)$, apples $(4.7 \%)$, and pears $(1.3 \%)$ at much lower quantities. In the UK, potato is the most important use (69\%), followed by apple (28\%) and pears (3\%).

\section{Discussion}

The substitution of copper-based fungicides has a high priority in European agricultural policy, but there is a lack of data on copper use, in particular with regard to total consumption of copper, leading to ambiguities regarding the quantities to be replaced. The present study aimed at filling this data gap, as a basis for the development of copper reduction pathways. Due to the lack of centralized databases on copper sales and uses in general, and in plant protection in particular, the present study combined an expert survey on use of copper in individual crops with land use data to estimate total use. While other studies assessing copper use in organic agriculture have either focussed on certain regions (e.g. Switzerland (Speiser et al., 20I5) or Germany (Kühne et al., 20I7)) or on specific crops (e.g. olives, citrus, tomatoes, potatoes (Katsoulas et al., 2020)), this study aims to provide an overall view on copper use by including all crops in 12 European countries, and therefore covering $84 \%$ of the European horticultural area. While the present survey takes into account reductions of copper limits (from $6 \mathrm{~kg}$ ha-1 $^{-1}$ to $28 \mathrm{~kg} \mathrm{ha}^{-1}$ in 7 years) after 2018 as a result of regulation (EU)2018/198I (European Commission, 2018), other surveys which were conducted before 2018 (Katsoulas et al., 2020, Kühne et al., 2017, Speiser et al., 2015) use the limits in force at that time.

The extraordinary wide spectrum of copper is reflected in the presence of more than 60 permitted and more than 40 real uses identified in this survey. The number of allowed and real uses reflects the proportion of the organically managed area in a country and relates to the climatic conditions, i.e. whether weather conditions are favourable to grow certain crops and to the severity of certain plant diseases. Therefore, countries such as Spain, Italy and France by far have the most permitted and real uses. The wide range of activity emphasizes the particular challenge for substitution of copper-based fungicides, requiring a broad range of solutions tailored to each crop and plant pathogen.

Permitted amounts of copper ranged from 1.2 to $4 \mathrm{~kg} \mathrm{ha}^{-1}$, with a focus on 3 to $4 \mathrm{~kg} \mathrm{ha}^{-1}$. In more than $50 \%$ of these cases (crop $\times$ country), experts assessed that farmers use on average less than half of the permitted copper quantities. These results are consistent with a Swiss survey among organic farmers covering the years 2009-2012 (Speiser et al., 2015), where utilisation rates below 50\% were found in nine out of 15 allowed uses. The lowest utilisation was found in cucumber, tomatoes, strawberries, blueberries, raspberries and cabbage (all below 25\%), followed by apricots, blackberries and carrots (25-50\%). In apple, cherries, pears, potatoes and celery, $50-80 \%$ of the maximal allowed amount was used, while utilisation in viticulture varied between $13 \%$ in downy mildew resistant ('PiWi') and $75 \%$ in susceptible cultivars. Low utilisation rates found for many crops in this and previous surveys (Katsoulas 
et al., 2020, Speiser et al., 2015) may reflect the high awareness of individual farmers to reduce the amount of copper, as well as the efforts of farmers' associations and national copper reduction strategies. High utilization rates in particular crops in most surveyed countries can be indicative for crop protection issues which are difficult to solve without copper use, such as for grapevine and downy mildew (Plasmopara viticola) (Gessler et al., 20I I). In other cases, high utilization rates mirror restrictive copper limits as e.g. for Belgium, where the permitted amount of copper is set to $2 \mathrm{~kg} \mathrm{ha}^{-1}$ (exceptions: potatoes $4 \mathrm{~kg} \mathrm{ha}^{-1}$, apples/pears $2.6 \mathrm{~kg} \mathrm{ha}^{-1}$ ), resulting in utilisation rates above $75 \%$ in most of the cases. In some crops, a high variability in the copper utilization rate between countries was observed. For example, in potatoes, on average between 10 and $100 \%$ of the maximal legally permitted amount is used depending on the country, which might reflect different climatic conditions and thus disease pressure. For potatoes and tomatoes in Italy, the copper use estimates in this survey are consistent with those of (Katsoulas et al., 2020), considering that in Italy, limits have been reduced to $4 \mathrm{~kg} \mathrm{ha}^{-1} \mathrm{y}^{-}$ I in the meanwhile. In some other cases, the two studies' estimates of real copper use differ from each other, often with higher estimates in Katsoulas et al. (2020). This discrepancy might reflect increased reduction efforts as a result of the reduced legally permitted maximum copper quantity after 2018 ((EU) 2018/198I (European Commission, 2018)). Furthermore, variability of copper uses depending on varieties or production systems could lead to different assessments by experts. For example, in olives, Katsoulas et al. (2020) found higher amounts of copper used in irrigated vs. non-irrigated systems, and in susceptible vs. less susceptible varieties, and Speiser et al. (2015) report much lower copper utilisation rates in downy mildew resistant ('PiWi') than in susceptible cultivars (13\% vs. 75\%).

In view of the intended copper replacement in the coming years, an estimate of the quantities of plant protection products needed for replacement is crucial. This survey estimates that approximately 3'300 $t$ of copper need to be substituted annually in the 12 surveyed countries to cover the needs of the current organic production area. Thus, with an average amount of $0.5 \mathrm{~kg}$ copper per ha and treatment, alternative products sufficient to treat $64^{\prime} 000 \mathrm{~km}^{2}$ once a year would be necessary just for the 12 surveyed countries. This calculation does not consider the foreseen increase in organically managed area and the potential increase of diseases due to climate change or the introduction of new plant pathogens. Verification of copper use data is not straight-forward, since there is a substantial lack of statistics on active substance use in general (Mesnage et al., 2021) and, correspondingly, also regarding copper use. At least for Germany and Switzerland, plausibility checks can be performed. In Switzerland, the sales of copper as plant protection product, are $50 \mathrm{t} \mathrm{y}^{-1}$ (Tamm et al., 2018). This survey's estimate

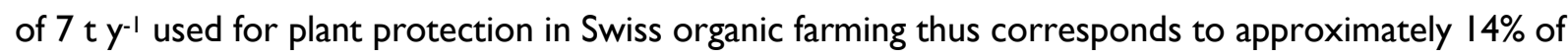
total copper use, which in turn is proportional to the organic farming area (i.e. $14 \%$ organic area share of total farmland in 2017, https://statistics.fibl.org/europe/area.html), and thus plausible. For Germany, Kühne et al. (2017) estimated a total use of copper of $26 \mathrm{t}$ in organic farming in 2013. The $42 \mathrm{t} \mathrm{y}^{-1}$ calculated in this study (corresponding to an increase of $61 \%$ ) are in accordance with these findings 
given the growth of the organic sector ( $+75 \%$ in horticultural area from 2013 to 2017 , statistics.fibl.org) and the partial compensation by successful copper reduction strategies.

Not surprisingly, copper consumption in individual countries correlates with the organic area in which copper use is allowed, which obviously in turn is affected by the size of the country, the share of organically managed land, the cultivated crops, and copper authorizations in these crops. There is a large difference in efforts to reduce copper inputs at national levels. For example, Germany has developed a very stringent strategy for copper reduction (https://kupfer.juliuskuehn.de/dokumente/upload/ff2Id_I60425_strategiepapier_kupfer_2.0_oktober_2015.pdf) given its wide range of copper-dependent crop/pathogen combinations (Kühne et al., 2017). As a result, copper use per ha on organic farms was significantly reduced in the past decade. However, there is a common understanding that with the current technology, no substantial further reduction is likely in the main crops, particularly in view of the increasing difficulties due to climate change and invasive diseases (Kühne et al., 2017). In Italy, Spain and France, systematic reduction strategies have been initiated later than in Germany and the potential is not yet fully exploited, especially in crops such as olives and nuts.

If crops were ranked in each country according to copper use, grapevine would be among the three most important copper usages in seven countries, followed by apple (five countries), potato and nuts (four countries each). Pears and vegetables were relatively important in three, and olives in two countries. At a European scale, olives, grapevine and nuts are the main drivers of overall copper use in organic farming, while crops like apples, pears and potatoes play a minor role. A plausibility check using estimates of Katsoulas et al. (2020) indicates that our estimates for olives presented here are rather conservative and real copper use in olives might even be higher, with a significant impact on overall European copper use. While grapevine is widely known as a main copper consuming crop (Dagostin et al., 20II, Lamichhane et al., 2018), the impact of olives as well as nuts and almonds on European copper use was not expected by most experts of this survey. This might result from the fact that these crops can only be cultivated in relatively few Mediterranean countries, and from the rapid growth of the organic production area in these countries (Tab. S4, supplementary data). For example, between 2004 and 2017, organically managed area of olives increased in Italy from 89'000 ha to 236'000 ha $(+163 \%)$, in Spain from $90^{\prime} 000$ ha to $195^{\prime} 000$ ha (+116\%), and in France from 0 ha to $4^{\prime} 700$ ha. Similarly, the area of organically managed almonds increased from 0 ha in 2004 to $138^{\prime} 000$ ha in 2017 in the 12 surveyed countries (mainly attributable to increases in Spain), and the area of organically managed nuts increased from 12'000 ha to $95^{\prime} 000$ ha in the same period ( $+690 \%$, increases in France, Bulgaria, Spain and Italy). In this survey, potatoes, which are generally considered to be highly copper consuming, ranked among the top-three copper consuming crops in four countries. Yet, their impact on copper consumption at European scale is rather small, contributing only to $1.2 \%$ of total consumed copper, most likely as a result of the relatively small cultivated area $(0.65 \%$ of the total organically managed area in the surveyed countries) and considerable efforts to reduce copper use. 
In view of the considerable amounts of copper to be replaced, it is evident that only a consequent combination of all preventive measures and new alternative products can be successful. The consequent exploitation of preventive measures is a core principle of organic farming, reflected in EU regulations ((EU) No 2018/848, (European Parliament and the Council, 2018)), guidelines of FAO/WHO (Codex Alimentarius Commission, 20I3) as well as in the private standards of IFOAM (IFOAM, 2019) and farmer associations. In the context of copper replacement, use of disease resistant cultivars, and, more recently, rain shelters in horticultural crops are efficient component strategies (Lang et al., 20I6, Kelderer et al., 20I8). The availability of resistant cultivars is a key factor in helping copper reduction. For example, large differences in copper dependency were described for different olive varieties having different levels of susceptibility to diseases (Katsoulas et al., 2020), and considerably lower amounts of copper are used in more resistant grapevine (PiWi) varieties (CasanovaGascón et al., 2019, Rousseau et al., 2013, Speiser et al., 2015). For example, Swiss organic farmers on average only use $13 \%$ of the maximally allowed copper amounts in PiWi varieties, in comparison to $73 \%$ in traditional, susceptible varieties (Speiser et al., 2015). In the Netherlands, where the use of copper as a plant protection product is not allowed, the yield of organic potato per ha could be increased by $80 \%$ by introducing new resistant potato varieties (Keijzer et al., 202I). In many countries, efforts are currently being made to open up markets for new resistant/tolerant varieties. However, preferences of consumers and/or retailers, concerning variety and related quality attributes often dictate what farmers should produce (e.g. reviewed by Nuijten et al. (2018)). As a consequence, the potential market of resistant/tolerant varieties has not been fully exploited yet. Overall, up to now, only little progress has been made in replacing susceptible cultivars in many crops (Nuijten et al., 2018). Nuijten et al. (2018) conclude that a successful market introduction of new varieties is only possible with strategies tailored to the specific context encompassing the entire supply chain from breeder to consumer.

The adoption of preventive strategies is often costly, time-consuming (e.g. planting of robust varieties in perennial crops, rain shelters), and risky for farmers if the market is not receptive (Tamm et al., 2004). Furthermore, changes of production systems may trigger the emergence of currently minor or secondary diseases or the development of virulent pathogen strains that may overcome varietal resistance. The first phenomenon was observed when apple scab resistant cultivars were planted at commercial scale: the consequent reduction of fungicides against the main pathogen let previously irrelevant diseases, such as Diplocarpon mali, become important (Wöhner \& Emeriewen, 2019). In the second case, for example new pathogenic races of apple scab overcoming resistance genes were continuously emerging (Belete \& Boyraz, 2017).

Some crops such as olives, almonds, and hazelnuts, are gaining importance for their healthy properties and subsequently their cropped area is constantly increasing. The national experts of our survey indicated that these crops are often grown with traditional methods, and comparably little effort has been invested into the development of novel strategies to prevent and control diseases and therefore 
to reduce copper use. On the other hand, experts indicated that farmers in most regions are willing to adopt disease preventive strategies that are easy to apply. However, even if all preventive crop protection strategies are implemented, there is still a significant need for alternative plant protection products, considering that the amount of copper to be substituted in European organic horticulture equals to approximately 3'300 t per year. There are several alternative products available (e.g. summarized in Tab. SI (Supplementary data) and by Andrivon and Savini (2018) and Dagostin et al. (20II)), but none can compete with copper, in terms of spectrum of activity, efficacy and price for growers. While some products with acceptable to good efficacy are available for the control of ascomycetes and basidiomycetes (e.g. sulphur, aluminium sulfate, potassium hydrogen carbonate, lime sulphur), the control of oomycetes and bacteria is provided only to a limited extent by some products. For example, aluminium sulfate and the biocontrol organisms Aureobasidium pullulans, Bacillus amyloliquefaciens, and Bacillus subtilis have reported uses against selected plant pathogenic bacteria (e.g. Erwinia amylovora in apples (Gusberti et al., 2015, Kunz, 2004, Broggini et al., 2005), Pseudomonas syringae pv. actinidae in Kiwi (de Jong et al., 2019), Erwinia carotovora in vegetables (Zhao et al., 2013), Xanthomonas arboricola pv. pruni in nectarines (Ladurner et al., 2016)). Therefore, crop protection in plants with a wide range of bacterial diseases (e.g. hazelnut, walnut, oranges) still heavily depends on copper-based plant protection products, even though the national experts of this survey assess that the potential of available alternatives is probably not fully exploited. Plant resistance inducers such as laminarin (Aziz et al., 2003) or COS/OGA (Clinckemaillie et al., 2017, van Aubel et al., 2014) may contribute to additional protection in critical conditions against certain pathogens, but none of the resistance inducers provides acceptable disease control in practice.

The urgent need for highly active fungicidal compounds of natural origin has been recognized (e.g. Dagostin et al. (20II)) and systematic screenings for novel compounds were initiated by several research groups as well as the industry. Promising new plant protection product candidates include an extract from Larix decidua (Thuerig et al., 2018), the monosaccharide tagatose derived from lactose (Ohara et al., 2008), an extract from liquorice (Glycyrrhiza glabra) (Scherf et al., 20I2), and a pelargonic acid-based product (Liu et al., 2014). Furthermore, refined inorganic compounds such as calcium carbonate, or calcium hydroxide have been further developed for this aim. If the alternatives are botanical extracts, upscaling to the staggering quantities needed will be a major challenge, while microorganisms are generally more readily up scaled in large fermenters (Thuerig \& Tamm, 2020). The evaluation and further development of alternatives represent an integral part of several EU-funded $\begin{array}{llll}\text { projects (e.g. RELACS (https://relacs-project.eu/), } & \text { FORESTSPECS }\end{array}$ (https://cordis.europa.eu/project/id/227239/reporting), PROLARIX (https://www.prolarix.eu/homepage.html), CO-FREE (http://www.co-free.net/), ORGANIC PLUS (https://organic-plus.net/)). Even though the most advanced compounds show promising levels of efficacy and seem to cover different uses, none of these alternatives has been authorised as an active substance for plant protection so far in the EU. The EU has a long and complex procedure to authorize 
the placing on the market of novel plant protection products, which requires substantial efforts and investments. (Thuerig \& Tamm, 2020). As the alternatives to copper will most likely be more expensive than the status quo, roadmaps that facilitate the transition need to be developed.

\section{Conclusions}

Organic farming is a rapidly growing market and has clearly left the status of niche production. The environmentally-friendly production of healthy food ("Farm2Fork" strategy, https://ec.europa.eu/food/horizontal-topics/farm-fork-strategy_en) is even at the heart of the European Green Deal set out to make Europe the first climate-neutral continent by 2050 (https:/lec.europa.eu/info/strategy/priorities-2019-2024/european-green-deal_en). Yet, climate change and invasive pathogens will increase the risk of crop losses due to existing and emerging diseases. To many of these, copper still provides a workable and affordable solution. It is clear that it will be extremely demanding to develop solutions for all of the current copper uses. Replacement of copper seems only feasible if (i) all preventive strategies and decision support systems are fully implemented and (ii) several affordable alternative plant protection products are successfully brought to the market and available in the required quantities. It is essential that national and international breeding programmes are intensified. In view of the staggering amount of copper to be replaced, scalability of production of alternative plant protection products is crucial. As copper alternatives will most likely be more expensive than the status quo, roadmaps that facilitate the transition to a no- or low-copper strategy need to be developed. Our survey clearly highlights the need of a centralized database on real use of plant protection products per crop, disease and year, which would allow to monitor the success of copper reduction strategies. 
Tab.I. Institutes involved in this expert survey.

\begin{tabular}{lll}
\hline Country & Organisation involved & Website \\
\hline Belgium & Bioforum & https://www.bioforum.be/ \\
Bulgaria & Bioselena & https://bioselena.com/ \\
Denmark & $\varnothing k o l o g i s k$ Landsforening & https://okologi.dk/ \\
Estonia & Estonian Organic Farming Foundation (EOFF) & http://www.maheklubi.ee/ \\
France & Institut de l'agriculture et de l'alimentation & http://itab.asso.fr/ \\
& biologiques (ITAB) & \\
Germany & Naturland & https://naturland.de/de/ \\
Hungary & Ökológiai Mezógazdasági Kutatóintézet (ÖMKi) & $\mathrm{https://www.biokutatas.hu/}$ \\
Italy & FederBio, & $\mathrm{https://feder.bio/}$ \\
& Fondazione Edmund Mach (FEM) & $\mathrm{https://www.fmach.it/}$ \\
Norway & Norwegian Institute of Bioeconomy Research & $\mathrm{https://www.nibio.no/en}$ \\
& (NIBIO) & \\
Spain & ecovalia & $\mathrm{https://www.ecovalia.org/}$ \\
Switzerland & Research Institute of Organic Agriculture (FiBL) & $\mathrm{https://www.fibl.org/de/}$ \\
United Kingdom & Soil Association & $\mathrm{https://www.soilassociation.org/}$ \\
\hline
\end{tabular}


Table 2. Restrictions of copper use in the private sector by farmers associations in 19 selected European countries (based on http://organicrules.org)

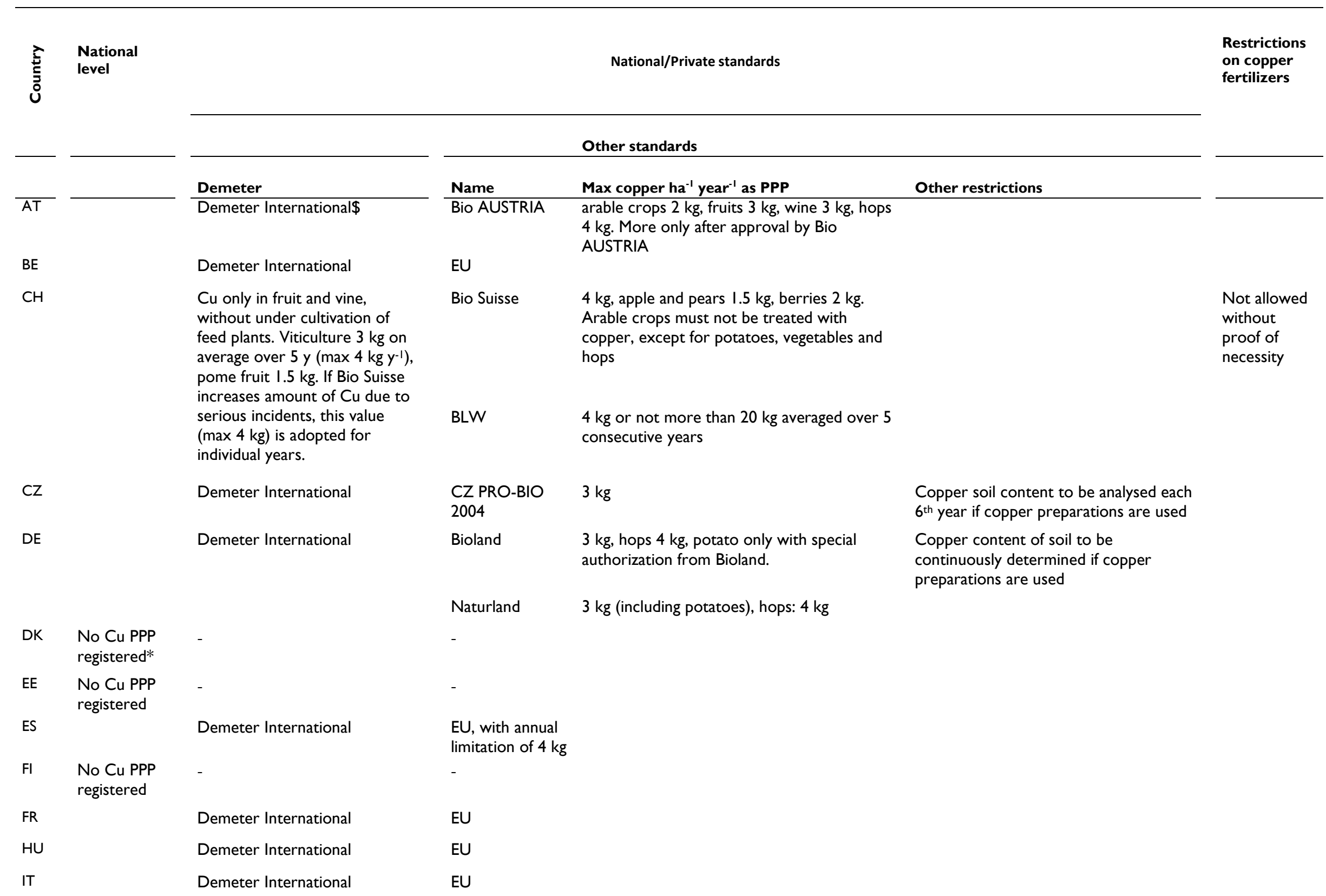


Not allowed (amounts of copper required exceed KRAV's limit for addition of heavy metals)

Soil Association $4 \mathrm{~kg}$, in compliance with PPP rules
Not allowed

without

proof of

necessity.

Maximum limits for heavy metals $(\mathrm{Pb}$, $\mathrm{Cd}, \mathrm{Cu}, \mathrm{Cr}, \mathrm{Hg}, \mathrm{Ni}, \mathrm{Zn}$ ) including inputs

by fertilizers, soil conditioners, PPP,

herbicides or indirect inputs by use in

animal husbandry (feed, feed minerals and medicines). Fertilizers/soil

conditioners to be analysed when high

concentrations of contaminants are

expected

$300 \mathrm{~g} \mathrm{ha}^{-1} \mathrm{y}^{-1}$

Up to max I

$\mathrm{kg}$ permitted

if shown that

arable land in

question

requires

additional

copper

Annual production plan required as

basis for use of any plant protection

substances from the list of allowed PPP

(Annex), agreement from inspection

body needed.

Perennial crops: $4 \mathrm{~kg}$ limit may be exceeded in a given year provided that average annual quantity actually used over a 7 year period.

\$ Demeter International: max $3 \mathrm{~kg}$ averaged over 7 years, preferably max $500 \mathrm{~g} \mathrm{ha-1}$ spray $^{-1}$; ${ }^{*}$ thus use in plant protection not allowed

AT Austria, BE Belgium, CH Switzerland, CZ Czechia, DE Germany, DK Denmark, EE Estonia, ES Spain, FI Finland, FR France, HU Hungary, IT Italy, NL Netherlands, NO Norway, PL Poland, RO Romania, SE Sweden, SI Slovenia, UK United Kingdom; \# 6 kg ha-1 $\mathrm{y}^{-1}$ according to Commission Regulation (EC) No 889/2008 of 5 September 2008 
Table 3. Copper use authorizations and estimated real use in perennial crops in organic farming (authorized use/ real use) in $\mathrm{kg}$ per ha and year in organic farming in the 12 surveyed European countries. Colours visualize intensity of use (from no use (white) to a maximum of $4 \mathrm{~kg}$ (dark blue)).

\begin{tabular}{|c|c|c|c|c|c|c|c|c|c|c|c|}
\hline $\begin{array}{l}\text { EPPO } \\
\text { code }^{\text {a }}\end{array}$ & Crop & Belgium & Bulgaria & France & Germany & Hungary & Italy & Norway & Spain & Switzerland & UK \\
\hline PRNDU & Almonds & & & $4 / 1.5$ & & & $4 / 4$ & & $4 / 2$ & & \\
\hline MABSD & Apples & $2.6 / 2.6$ & $4 / 4$ & $4 / 3$ & $3 / 1.3$ & $3 / 3$ & $4 / 1.5$ & $3 / 3$ & $4 / 1.5$ & $4 / 0.9$ & $4 / 2$ \\
\hline PRNAR & Apricots & & $2 / 1.5$ & $4 / 2.5$ & & $3 / 3$ & $4 / 4$ & & & $4 / 2$ & \\
\hline PEBAM & Avocados & & & & & & $4 / 0$ & & & & \\
\hline \multirow[t]{4}{*}{ MUBPA } & Bananas & & & & & & & & & & \\
\hline & Berries, no details/n.e.c. & & $4 / 2.5$ & & $3 / 0.7$ & & $4 / 0$ & & & $4 / 2$ & \\
\hline & Berries, other & & & & 0.7 & & & & & & \\
\hline & Black chokeberries & & & & & & & & & & \\
\hline RUBFR & Blackberries & & & & $3 / 0.7$ & & $4 / 3$ & & & $4 / 2$ & \\
\hline VACMY & Blueberries & & & & $3 / 0.7$ & & $4 / 3$ & & & $4 / 2$ & \\
\hline RHACT & Buckthorn & & & & & & & & & & \\
\hline PRfalschV & Cherries & $2 / 2$ & $4 / 3.5$ & $4 / 2.5$ & $4 / 3$ & & $4 / 4$ & & & $4 / 2$ & $4 / 0$ \\
\hline \multirow[t]{2}{*}{ CONSVA } & Chestnuts & & & $4 / 0$ & & & & & & & \\
\hline & Citrus no detail & & & $4 / 2$ & & & $4 / 2$ & & $4 / 2.5$ & & \\
\hline RIBNI & Currants & & & $4 / 0.3$ & & & $4 / 3$ & & & & \\
\hline PHXDA & Dates & & & & & & & & & & \\
\hline \multirow[t]{5}{*}{ FIUCA } & Figs & & & & & & $4 / 0$ & & & & \\
\hline & Fruit, temperate, no details & & & & & & & & & & \\
\hline & Fruit, temperate, other & & & & & & & & & & \\
\hline & Fruit, tropical and subtropical, no deta & & & & & & & & & & \\
\hline & Fruit, tropical and subtropical, other & & & & & & & & & & \\
\hline CIDPA & Grapefruit/Pomelos & & & $4 / 2.5$ & & & & & & & \\
\hline \multirow[t]{3}{*}{ 1VITG } & Grapes, no details & $2 / 2$ & $4 / 4$ & $4 / 4$ & $3 / 2.3$ & $3 / 3$ & $4 / 4$ & & & $4 / 2.9$ & $4 / 0$ \\
\hline & Grapes, raisins & & & $4 / 4$ & & & & & & l & \\
\hline & Grapes, table & & & $4 / 4$ & & & $4 / 4$ & & $4 / 2$ & $4 / 2.9$ & \\
\hline 1VITG & Grapes, wine & $2 / 2$ & $4 / 4$ & $4 / 4$ & $3 / 2.3$ & $3 / 3$ & $4 / 4$ & & $4 / 2$ & $4 / 2.9$ & $4 / 0$ \\
\hline CYLAV & Hazelnuts & & & $4 / 4$ & & & $4 / 4$ & & $1.2 / 1$ & & \\
\hline HOPSS & Hops & $2 / 2$ & & $4 / 4$ & $4 / 3.7$ & & & & & $4 / 4$ & \\
\hline ATICH & Kiwis & & & $4 / 3.3$ & & & $4 / 4$ & & & & \\
\hline CIDLI & Lemons and limes & & & $4 / 2$ & & & $4 / 3$ & & & & \\
\hline \multirow[t]{3}{*}{ PRNPN } & Nectarines & & $4 / 2$ & $4 / 2.5$ & & & $4 / 4$ & & $4 / 1.5$ & & \\
\hline & Nuts, no details & & $4 / 1.7$ & $4 / 4$ & & $4 / 3$ & & & & & \\
\hline & Nuts, other & & & & & & & & & & \\
\hline \multirow[t]{2}{*}{ OLVEU } & Olives, no details & & & $4 / 2$ & & & 43 & & $4 \quad 2.8$ & & \\
\hline & Olives, oil & & & $4 / 2$ & & & $4 / 3$ & & $4 / 2.8$ & & \\
\hline CIDSI & Oranges & & & $4 / 2$ & & & $4 / 2$ & & $4 / 2.5$ & & \\
\hline \multirow[t]{2}{*}{ PRNPS } & Peaches & & $4 / 2.5$ & $4 / 2.5$ & $3 / 0$ & $4 / 3$ & $4 /$ & & & & \\
\hline & Peaches and nectarines, no details & & & & & & & & & & \\
\hline PYUCO & Pears & $2.6 / 2.6$ & $4 / 2.5$ & $4 / 3$ & $3 / 1.3$ & $4 / 3.5$ & $4 / 4$ & $3.5 / 2.5$ & & $4 / 1.2$ & $4 / 2$ \\
\hline PIAVE & Pistachios & & & & & & & & & & \\
\hline \multirow[t]{3}{*}{ 3PLUC } & Plums & $2 / 2$ & $4 / 1.8$ & $4 / 2$ & $4 / 2.5$ & & $4 / 4$ & $3 / 0$ & & $4 / 1.5$ & $4 / 0$ \\
\hline & Pome fruit, no details & & & & & & & & & & \\
\hline & Pome fruit, other & & & & & & & & & & \\
\hline PUNGR & Pomegranate & & & & & & & & & & \\
\hline CYDOB & Quinces & & & & & & & & & & \\
\hline \multirow[t]{3}{*}{ RUBID } & Raspberries & & & $4 / 0.6$ & $3 / 0.5$ & & $4 / 3$ & & & $4 / 0.5$ & \\
\hline & Stone fruit, no details & & & & $/ 1$ & & & & & $4 / 4$ & $3 / 0$ \\
\hline & Stone fruit, other & & $4 / 1.5$ & & $3 / 1$ & & & & $4 /$ na & $4 / 4$ & $3 / 0$ \\
\hline FRAAN & Strawberries & & $4 / 1.2$ & $4 / 2$ & $3 / 0.8$ & & $4 / 4$ & & $4 / 0$ & $2 / 0.4$ & $3 / 0$ \\
\hline CIDRE & Tangerine & & & & & & & & & & \\
\hline NNNTE & Tea & & & & & & & & & & \\
\hline IUGRE & Walnuts, with shell & & & $4 /$ na & $3 / 0$ & & $4 / 4$ & & $2 / \mathrm{na}$ & $4 / 0$ & \\
\hline
\end{tabular}


Table 4. Copper use authorizations and estimated real use (authorized use/ real use) in annual crops in $\mathrm{kg}$ per ha and year in organic farming in the 12 surveyed European countries. Colours visualize intensity of use (from no use (white) to a maximum of $4 \mathrm{~kg}$ (dark blue)).

\begin{tabular}{|c|c|c|c|c|c|c|c|c|c|c|c|}
\hline $\begin{array}{l}\text { EPPO } \\
\text { code }^{a}\end{array}$ & Crop & Belgium & Bulgaria & Fracne & Germany & Hungary & Italy & Norway & Spain & Switzerland & UK \\
\hline $\mathrm{HHHHH}$ & Aromatic, medical and culinary plants & & & & & & & & & & \\
\hline 1ASPG & Asparagus & & & & & & & & & & \\
\hline SOLME & Aubergine & & & & & & $4 / 4$ & & & $1.3 / 1.3$ & \\
\hline 3BARC & Barley & & $4 / 0.5$ & & & $4 / 0$ & $4 / 0.5$ & & $4 / 0.5$ & & \\
\hline VICFX & Beans & & & $4 / 2$ & & & & & $4 / 4$ & & \\
\hline 3BRAC & Brassicas & & & & & & $4 / 3$ & & $2 / \mathrm{na}$ & $4 / 2$ & \\
\hline FAGES & Buckwheat & & & & & & & & & & \\
\hline DAUCS & Carrots & & & $4 / 2$ & & & & & $2 /$ na & $4 / 2.8$ & \\
\hline \multicolumn{3}{|c|}{ APUGR \& AICeleriac and celery } & & & & & & & & $4 / 2.7$ & \\
\hline CICIN & Chicory / red chicory & $2 / 2$ & & $4 / 2$ & & & & & & & \\
\hline CMJSP & Cotton & & & & & & & & & & \\
\hline LIUUT & Flax & & & & & & & & & & \\
\hline BEAVC & Fodder beet & & & & & & & & & $4 / 0$ & \\
\hline ZEAMX & Grain maize and corn cob mix & & & & & & & & & & \\
\hline \multirow[t]{3}{*}{ CNISA } & Hemp & & & & & & & & & & \\
\hline & Industrial crops, no details & & & & & & & & & & \\
\hline & Industrial crops, other & & & & & & & & & & \\
\hline ALLPO & Leeks & & & & & & & & & & \\
\hline LENCU & Lentils & & & & & & & & & & \\
\hline LACSA & Lettuce & & & & & & & & $4 /$ na & & \\
\hline LIUUT & Linseed (oil flax) & & & & & & $4 / 0$ & & & & \\
\hline 3LUPC & Lupine & & & & & & & & & & \\
\hline \multirow[t]{3}{*}{ OATSS } & Oats & & & & & & $4 / 0$ & & & & \\
\hline & Oilseeds, no details & & & & & & & & & & \\
\hline & Oilseeds, other, n.e.c & & & & & & $4 / 0$ & & & & \\
\hline \multirow[t]{2}{*}{ ALLCE } & Onions & & & $4 / 2$ & & & & & & & \\
\hline & $\begin{array}{l}\text { Other cereals n.e.c. } \\
\text { Other fodder roots }\end{array}$ & & & & & & $4 / 0$ & & & & \\
\hline PEAAC & Peas & & & $4 / 2$ & $3 / 0$ & & & & & & \\
\hline 1CPSG & Pepper/Capsicum & & & & & & & & & & \\
\hline \multirow[t]{4}{*}{ SOLTU } & Potatoes & $4 / 4$ & $4 / 0.5$ & $4 / 4$ & $3 / 1.6$ & & $4 / 3$ & & $4 /$ na & $4 / 2.8$ & $4 / 3.7$ \\
\hline & Protein crops, no details & & & & & & $4 / 0.5$ & & & & \\
\hline & Protein crops, other & & & & & & & & & & \\
\hline & Pulses & & & & & $4 / 2$ & & & & & \\
\hline CUUPE & Pumpkin seeds & & & & & & & & & $4 / 0$ & \\
\hline 3TURC & Rape and turnip rape & & & & & & $4 / 2$ & & & & \\
\hline \multirow[t]{3}{*}{ ORYSA } & Rice & & & & & & $4 / 0$ & & & & \\
\hline & Root crops, no details & & & & & & & & & & \\
\hline & Root crops, other, n.e.c & & & $4 / 2$ & & & $4 / 2$ & & & $4 / 1$ & $3 / 0$ \\
\hline 3RYEC & Rye & & & & & & $4 / 1$ & & & & $3 / 0$ \\
\hline \multirow[t]{2}{*}{ GLXMA } & Soybeans & & & & & & $4 / 0$ & & & & \\
\hline & Spelt & & & & & & & & & & \\
\hline SPQOL & Spinach & & & & & & & & & & \\
\hline BEAVP & Sugar beet & & & & & & $4 / 1$ & & $2 /$ na & $4 / 0$ & $3 / 0$ \\
\hline 1SACG & Sugarcane & & & & & & $4 / 4$ & & & & \\
\hline \multirow[t]{3}{*}{ HELAN } & Sunflower seed & & & & & & $4 / 0$ & & & & \\
\hline & Textile crops, no details & & & & & & & & & & \\
\hline & Textile crops, other, n.e.c. & & & & & & & & & & \\
\hline NIOTA & Tobacco & & & & & & & & & & \\
\hline \multirow{8}{*}{$\begin{array}{l}\text { LYPXS/LY } \\
\text { 3TRIC }\end{array}$} & $x$ Tomatoes & & & $4 / 4$ & & & $4 / 4$ & & $4 / 4$ & $4 / 0.2$ & \\
\hline & Triticale & & & & & & & & & & \\
\hline & Vegetables, fruit & & $4 / 0.2$ & & & & $4 / 4$ & & $4 / 4$ & & \\
\hline & Vegetables, leafy or stalked & & & $4 / 2$ & & & & & & & \\
\hline & Vegetables, Broccoli & & & $4 / 2$ & & & & & & & \\
\hline & Vegetables, no details & & & $4 / 2$ & & & & & & & \\
\hline & Vegetables, other & & & $4 / 2$ & & & & & & & \\
\hline & Vegetables, root tuber and bulb & & & $4 / 2$ & & & & & $4 / 0$ & & \\
\hline \multirow[t]{6}{*}{ 3WHEC } & Wheat & & & & & & $4 / 0.1$ & & & & \\
\hline & Greenhouse tomato & $2 / 1$ & & $4 / 2$ & $3 / 1.4$ & & $4 / 4$ & & $4 / 2$ & $4 / 0.2$ & $2 / 0$ \\
\hline & Greenhouse cucumber & & & $4 / 2$ & & & & & $4 /$ & $4 / 0.2$ & $2 / 0$ \\
\hline & Greenhouse other & & & $4 / 2$ & $3 / 1.4$ & & & & $4 / 2$ & & \\
\hline & Greenhouse ornamentals & $2 / 1$ & & $4 / 2$ & $3 / 1.5$ & & & & $4 / 2$ & $4 / 0$ & $2 / 0$ \\
\hline & Outdoors ornamentals & & $4 / 2.9$ & $4 / 2$ & & & & & $4 / 2$ & & \\
\hline
\end{tabular}

a EPPO codes according EPPO Global Database. https://gd.eppo.int 
Table 5. Overview on copper utilization rates in organic farming in 12 selected European countries.

\begin{tabular}{|c|c|c|c|c|c|c|c|c|c|c|c|c|c|c|c|c|c|c|c|c|c|}
\hline \multirow[b]{2}{*}{ Utilization rates $^{a}$} & \multicolumn{2}{|c|}{ Belgium } & \multicolumn{2}{|c|}{ Bulgaria } & \multicolumn{2}{|c|}{ France } & \multicolumn{2}{|c|}{ Germany } & \multicolumn{2}{|c|}{ Hungary } & \multicolumn{2}{|c|}{ Italy } & \multicolumn{2}{|c|}{ Norway } & \multicolumn{2}{|c|}{ Spain } & \multicolumn{2}{|c|}{$\begin{array}{c}\text { Switzer- } \\
\text { land }\end{array}$} & \multicolumn{2}{|c|}{ UK } & \multirow[t]{2}{*}{$\begin{array}{c}\begin{array}{c}\text { Overal } \\
(\%)^{d}\end{array}\end{array}$} \\
\hline & No. $^{b}$ & $\%^{\mathrm{c}}$ & No. & $\%$ & No. & $\%$ & No. & $\%$ & No. & $\%$ & No. & $\%$ & No. & $\%$ & No. & $\%$ & No. & $\%$ & No. & $\%$ & \\
\hline $0-0.25$ & 0 & 0.0 & 3 & 17.6 & 3 & 6.8 & 7 & 35.0 & 1 & 11.1 & 15 & 31.3 & 1 & 33.3 & 4 & 19.0 & 12 & 40.0 & 13 & 81.3 & 27 \\
\hline $0.26-0.5$ & 2 & 18.2 & 5 & 29.4 & 24 & 54.5 & 7 & 35.0 & 1 & 11.1 & 5 & 10.4 & 0 & 0.0 & 9 & 42.9 & 8 & 26.7 & 2 & 12.5 & 29 \\
\hline $0.51-0.75$ & 0 & 0.0 & 5 & 29.4 & 7 & 15.9 & 3 & 15.0 & 2 & 22.2 & 9 & 18.8 & 1 & 33.3 & 4 & 19.0 & 6 & 20.0 & 0 & 0.0 & 17 \\
\hline $0.76-1$ & 9 & 81.8 & 4 & 23.5 & 10 & 22.7 & 3 & 15.0 & 5 & 55.6 & 19 & 39.6 & 1 & 33.3 & 4 & 19.0 & 4 & 13.3 & 1 & 6.3 & 27 \\
\hline Total permitted uses & 11 & & 17 & & 44 & & 20 & & 9 & & 48 & & 3 & & 21 & & 30 & & 16 & & \\
\hline
\end{tabular}

a Utilization rates: (estimated real copper use)/(permitted use per crop); b No. : Number of crops per utilization rate category; c \% Percentage of crops per utilization rate category, ${ }^{\mathrm{d}}$ Overall (\%): (number of cases per utilization rate category)/(total number of allowed cases)

Table 6. Maximum permitted amounts of copper $\left(t y^{-1}\right)$, total estimated real use $\left(t y^{-1}\right)$, and percentage utilisation in organic farming in the 12 surveyed European countries.

\begin{tabular}{|c|c|c|c|c|c|c|c|c|c|c|c|c|c|}
\hline & $\begin{array}{l}\frac{\xi}{5} \\
\frac{\bar{\sigma}}{0} \\
\varnothing\end{array}$ & $\begin{array}{l}\frac{\pi}{\frac{\pi}{\pi}} \\
\frac{\pi}{5} \\
\overline{0}\end{array}$ & 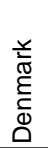 & $\begin{array}{l}\frac{\pi}{\frac{\pi}{L}} \\
\frac{0}{\tilde{D}} \\
\text { W. }\end{array}$ & 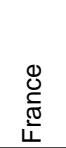 & 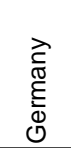 & 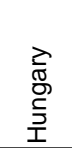 & 產 & $\begin{array}{l}\sum_{0}^{\overrightarrow{0}} \\
\text { i }\end{array}$ & $\begin{array}{l}\frac{5}{\pi} \\
\text { की } \\
\text { की }\end{array}$ & 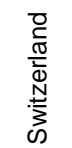 & 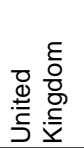 & 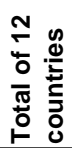 \\
\hline Maximum permitted quantities ( $\mathrm{t}$ ) & 3.9 & 248 & 0 & 0 & 546 & 91 & 34.4 & 3253 & 0.6 & 2038 & 10.4 & 11.5 & 6236 \\
\hline Total estimated real use ( $\mathrm{t}$ ) & 3.9 & 67 & 0 & 0 & 473 & 42 & 22.1 & 1556 & 0.5 & 1081 & 7.1 & 6.2 & 3259 \\
\hline Percentage utilisation ${ }^{a}$ & $100 \%$ & $27 \%$ & & & $87 \%$ & $46 \%$ & $64 \%$ & $48 \%$ & $78 \%$ & $53 \%$ & $68 \%$ & $54 \%$ & $52 \%$ \\
\hline
\end{tabular}

a Percentage utilisation: (Total estimated real use $(t)) /($ Maximum permitted quantities $(t)$ ) 
Tab 7. Total estimated copper consumption $\left(t y^{-1}\right)$ in organic farming in the 12 surveyed European countries in different horticultural crops (temperate fruits, grapes, olives, nuts, vegetables including potato). Grey bars visualize the relative contribution of a crop to overall copper consumption in an individual country.

\begin{tabular}{|c|c|c|c|c|c|c|c|c|c|c|c|}
\hline Crops & Belgium & Bulgaria & France & Germany & Hungary & Italy & Norway & Spain & $\begin{array}{l}\text { Switzer- } \\
\text { land }\end{array}$ & UK & $\begin{array}{l}\text { Total per } \\
\text { crop }\end{array}$ \\
\hline Almonds & 0 & 0 & 0 & 0 & 0 & 70 & 0 & 248 & 0 & 0 & 318 \\
\hline Apples & 0.5 & 2.4 & 31 & 7.9 & 8.1 & 9.3 & 0.5 & 1.8 & 0.3 & 1.8 & 64 \\
\hline Apricots & 0 & 0 & 2.6 & 0 & 0.6 & 12 & 0 & 0 & 0 & 0 & 16 \\
\hline Barley & 0 & 0.6 & 0 & 0 & 0 & 20 & 0 & 33 & 0 & 0 & 54 \\
\hline Berries, nd & 0 & 4.2 & 0 & 0 & 0 & 0 & 0 & 0 & 0.4 & 0 & 5 \\
\hline Blueberries & 0 & 0 & 0 & 0 & 0 & 0 & 0 & 0 & 0 & 0 & 0 \\
\hline Brassicas & 0 & 0 & 0 & 0 & 0 & 19 & 0 & 0 & 0 & 0 & 19 \\
\hline Cherries & 0.03 & 6.2 & 1.1 & 0 & 0 & 16 & 0 & 0 & 0 & 0 & 23 \\
\hline Citrus, nd & 0 & 0 & 0.8 & 0 & 0 & 21 & 0 & 0 & 0 & 0 & 22 \\
\hline Currants & 0 & 0 & 0 & 0 & 0 & 0 & 0 & 0 & 0 & 0 & 0 \\
\hline Grapes & 0.1 & 16 & 314 & 17 & 5.1 & 422 & 0 & 214 & 2.9 & 0 & 991 \\
\hline Hazelnuts & 0 & 0 & 0 & 0 & 0 & 49 & 0 & 0 & 0 & 0 & 49 \\
\hline Hops & 0.03 & 0 & 0 & 0.7 & 0 & 0 & 0 & 0 & 0 & 0 & 1 \\
\hline Kiwis & 0 & 0 & 0 & 0 & 0 & 22 & 0 & 0 & 0 & 0 & 22 \\
\hline Lemons and limes & 0 & 0 & 0 & 0 & 0 & 24 & 0 & 0 & 0 & 0 & 24 \\
\hline Nectarines & 0 & 0 & 0.5 & 0 & 0 & 1.3 & 0 & 0.8 & 0 & 0 & 3 \\
\hline Nuts, nd & 0 & 31 & 49 & 0 & 6.1 & 0 & 0 & 0 & 0 & 0 & 86 \\
\hline Olives, oil & 0 & 0 & 9.5 & 0 & 0 & 707 & 0 & 546 & 0 & 0 & 1263 \\
\hline Oranges & 0 & 0 & 0 & 0 & 0 & 42 & 0 & 14 & 0 & 0 & 56 \\
\hline Peaches & 0 & 0.6 & 1.1 & 0 & 0.2 & 8.9 & 0 & 0 & 0 & 0 & 11 \\
\hline Pears & 0.2 & 0 & 3.6 & 0.5 & 0.7 & 8.1 & 0.02 & 0 & 0.1 & 0.2 & 14 \\
\hline Plums & 0 & 4.8 & 4.1 & 0 & 0 & 4.9 & 0 & 0 & 0 & 0 & 14 \\
\hline Potatoes & 2.9 & 0 & 12 & 14 & 0 & 3.9 & 0 & 0 & 2.3 & 4.2 & 39 \\
\hline Protein crops, nd & 0 & 0 & 0 & 0 & 0 & 25 & 0 & 0 & 0 & 0 & 25 \\
\hline Pulses & 0 & 0 & 0 & 0 & 1.1 & 0 & 0 & 0 & 0 & 0 & 1 \\
\hline Rape and turnip rap & 0 & 0 & 0 & 0 & 0 & 4.1 & 0 & 0 & 0 & 0 & 4 \\
\hline Raspberries & 0 & 0 & 0 & 0 & 0 & 0 & 0 & 0 & 0 & 0 & 0 \\
\hline Root crops, other & 0 & 0 & 1.3 & 0 & 0 & 0.8 & 0 & 0 & 0 & 0 & 2 \\
\hline Rye & 0 & 0 & 0 & 0 & 0 & 0 & 0 & 0 & 0 & 0 & 0 \\
\hline Stone fruit, nd & 0 & 0 & 0 & 1.1 & 0 & 0 & 0 & 0 & 0.4 & 0 & 1 \\
\hline Strawberries & 0 & 0 & 0 & 0 & 0 & 1.0 & 0 & 0 & 0 & 0 & 2 \\
\hline Sugar beet & 0 & 0 & 0 & 0 & 0 & 0 & 0 & 0 & 0 & 0 & 0 \\
\hline Vegetables, fruit & 0 & 0 & 0 & 0 & 0 & 41 & 0 & 23 & 0 & 0 & 63 \\
\hline Vegetables, nd & 0 & 0 & 42 & 0 & 0 & 0 & 0 & 0 & 0.6 & 0 & 42 \\
\hline Walnuts, with shell & 0 & 0 & 0 & 0 & 0 & 5.9 & 0 & 0 & 0 & 0 & 6 \\
\hline Wheat & 0 & 0 & 0 & 0 & 0 & 18 & 0 & 0 & 0 & 0 & 18 \\
\hline Total per country & 3.7 & 67 & 464 & 42 & 22 & 1556 & 0.5 & 1081 & 7.1 & 6.2 & 3259 \\
\hline
\end{tabular}


Table 8. Total estimated copper consumption $\left(t y^{-1}\right)$ in organic farming in the 12 surveyed European countries. Crops were aggregated into crop categories (for details see supplementary).

\begin{tabular}{lcc}
\hline Crop categories $^{\mathrm{a}}$ & $\begin{array}{c}\text { Total copper use } \\
\text { (t per year) }\end{array}$ & Percentage (\%) \\
\hline Olives & 1263 & 38.8 \\
Grapes & 991 & 30.4 \\
Nuts & 459 & 14.1 \\
Vegetables & 106 & 3.2 \\
Citrus fruit & 102 & 3.1 \\
Pome fruit & 78 & 2.4 \\
Cereals & 72 & 2.2 \\
Stone fruit & 67 & 2.1 \\
Potatoes & 39 & 1.2 \\
Protein crops & 26 & 0.8 \\
Arable crops & 25 & 0.8 \\
Kiwis & 22 & 0.7 \\
Berries & 7.3 & 0.2 \\
Hops & 0.92 & 0.0 \\
\hline Total & 3258 & 100.0 \\
\hline
\end{tabular}

a for categories see supplementary data 


\section{References}

Andrivon D, Savini I, 2018. Peut-on se passer du cuivre en protection des cultures biologiques? Synthèse du rapport d'expertise scientifique collective. éditions Quae: INRA.

Ayres PG, 2004. Alexis Millardet: France's forgotten mycologist. Mycologist 18, 23-6, https://doi.org/10.1017/S0269915X04001090.

Aziz A, Poinssot B, Daire X, et al., 2003. Laminarin elicits defense responses in grapevine and induces protection against Botrytis cinerea and Plasmopara viticola. Molecular Plant-Microbe Interactions 16, 1118-28, https://doi.org/10.1094/MPMI.2003.16.12.1118.

Belete T, Boyraz N, 2017. Critical review on apple scab (Venturia inaequalis) biology, epidemiology, economic importance, management and defense mechanisms to the causal agent. Journal of Plant Physiology and Pathology 5, 2, https://doi.org/10.4172/2329955X.1000166.

Biodynamic Federation Demeter, 2021. Production, Processing and Labelling. International Standard for the use and certification of Demeter, Biodynamic and related trademarks (As of: July $2020 / 1^{\text {st }}$ circulation). In.

Bouma E, 2005. Development of comparable agroclimatic zones. Bulletin OEPP/EPPO Bulletin 35, 233-8.

Broggini GA, Duffy B, Holliger E, Schärer H-J, Gessler C, Patocchi A, 2005. Detection of the fire blight biocontrol agent Bacillus subtilis BD170 (Biopro®) in a Swiss apple orchard. European Journal of Plant Pathology 111, 93-100, https://doi.org/10.1007/s10658-004-1423$\underline{x}$.

Casanova-Gascón J, Ferrer-Martín C, Bernad-Eustaquio A, et al., 2019. Behavior of vine varieties resistant to fungal diseases in the Somontano Region. Agronomy 9, 738, https://doi.org/10.3390/agronomy9110738.

Clinckemaillie A, Decroës A, van Aubel G, et al., 2017. The novel elicitor COS-OGA enhances potato resistance to late blight. Plant pathology 66, 818-25, https://doi.org/10.1111/ppa.12641. Codex Alimentarius Commission, 2013. Guidelines for the Production, Processing, Labelling and Marketing of Organically Produced Foods. In. (CXG-32-1999.)

Dagostin S, Schärer H-J, Pertot I, Tamm L, 2011. Are there alternatives to copper for controlling grapevine downy mildew in organic viticulture? Crop Protection 30, 776-88, https://doi.org/10.1016/i.cropro.2011.02.031.

de Jong H, Reglinski T, Elmer PA, et al., 2019. Integrated use of Aureobasidium pullulans strain CG163 and Acibenzolar-S-methyl for management of bacterial canker in kiwifruit. Plants 8, 287, https://doi.org/10.3390/plants8080287.

DG SANCO, 2013. Working document on emergency situations according to Article 53 of Regulation (EC) No 1107/2009.

European and Mediterranean Plant Protection Organisation EPPO, 2021. https://www.eppo.int/ACTIVITIES/plant protection products/registered products.

European Commission, 2018. Commission implementing regulation (EU) 2018/1981 of 13 December 2018 renewing the approval of the active substances copper compounds, as candidates for substitution, in accordance with Regulation (EC) No 1107/2009 of the European Parliament and of the Council concerning the placing of plant protection products on the market, and amending the Annex to Commission Implementing Regulation (EU) No 540/2011. European Commission, 2021a. Commission Implementing Regulation (EU) 2021/1165 of 15 July 2021 authorising certain products and substances for use in organic production and establishing their lists.

European Commission, 2021b. Consolidated text: Commission Implementing Regulation (EU) No 540/2011 of 25 May 2011 implementing Regulation (EC) No 1107/2009 of the European Parliament and of the Council as regards the list of approved active substances (Text with EEA relevance). 
European Commission, 2021c. https://ec.europa.eu/food/plants/pesticides/eu-pesticidesdatabase en.

European Parliament and the Council, 2009. Regulation (EC) No 1107/2009 of the European parliament and of the council of 21 October 2009 concerning the placing of plant protection products on the market and repealing Council Directives 79/117/EEC and 91/414/EEC.

European Parliament and the Council, 2018. Regulation (EU) 2018/848 of the European Parliament and of the Council of 30 May 2018 on organic production and labelling of organic products and repealing Council Regulation (EC) No 834/2007.

European Parliament and the Council, 2019. Regulation (EU) 2019/1009 of the European Parliament and of the Council of 5 June 2019 laying down rules on the making available on the market of EU fertilising products and amending Regulations (EC) No 1069/2009 and (EC) No 1107/2009 and repealing Regulation (EC) No 2003/2003.

Finckh MR, van Bruggen AH, Tamm L, eds, 2015. Plant diseases and their management in organic agriculture. St. Paul, Minnesota: APS Press.

Gessler C, Pertot I, Perazzolli M, 2011. Plasmopara viticola: a review of knowledge on downy mildew of grapevine and effective disease management. Phytopathol Mediterr 50, 3-44, http://www.jstor.org/stable/26458675.

Gusberti M, Klemm U, Meier MS, Maurhofer M, Hunger-Glaser I, 2015. Fire blight control: the struggle goes on. A comparison of different fire blight control methods in Switzerland with respect to biosafety, efficacy and durability. International Journal of Environmental Research and Public Health 12, 11422-47, https://doi.org/10.3390/ijerph120911422.

IFOAM, 2019. The IFOAM norms for organic production and processing. Version 2014. In.: IFOAM-Organics International.

Karimi B, Masson V, Guilland C, et al., 2021. Ecotoxicity of copper input and accumulation for soil biodiversity in vineyards. Environmental Chemistry Letters, 1-18, https://doi.org/10.1007/s10311-020-01155-x.

Katsoulas N, Løes A-K, Andrivon D, et al., 2020. Current use of copper, mineral oils and sulphur for plant protection in organic horticultural crops across 10 European countries. Organic Agriculture 10, 159-71, https://doi.org/10.1007/s13165-020-00330-2.

Keijzer P, van Bueren ETL, Engelen CJM, Hutten RCB, 2021. Breeding late blight resistant potatoes for organic farming-a collaborative model of participatory plant breeding: the Bioimpuls Project. Potato Research, https://doi.org/10.1007/s11540-021-09519-8.

Kelderer M, Casera C, Lardschneider E, Telfser J. Field trials in apple orchards with different covering methods to reduce plant protection treatments and yield losses due to pests and diseases. Proceedings of the Proceedings of the 18th International Conference on Organic Fruit-Growing, 2018. online, 64-70.

Kühne S, Roßberg D, Röhrig P, et al., 2017. The use of copper pesticides in Germany and the search for minimization and replacement strategies. Organic Farming 3, 66-75, https://doi.org/10.12924/of2017.03010066.

Kunz S. Development of" Blossom-Protect"-a yeast preparation for the reduction of blossom infections by fire blight. Proceedings of the Ecofruit-11th International Conference on Cultivation Technique and Phytopathological Problems in Organic Fruit-Growing: Proceedings to the Conference from 3rd February to 5th February 2004 at Weinsberg/Germany, 2004, 10812.

La Torre A, lovino V, Caradonia F, 2018. Copper in plant protection: current situation and prospects. Phytopathologia Mediterranea 201-36, https://doi.org/10.14601/Phytopathol Mediterr-23407.

Ladurner E, Fiorentini F, Lucchi A, Piergiacomi M, Benuzzi M, 2016. Bacillus amyloliquefaciens strain D747 (Amylo-X®): control trials against powdery mildew on bell pepper, Monilinia laxa on apricot and Xanthomonas arboricola pv. pruni on nectarine. Atti, Giornate Fitopatologiche, Chianciano terme (Siena), 8-11 marzo 2016, Volume secondo, 155-62. 
Lamichhane JR, Osdaghi E, Behlau F, Köhl J, Jones JB, Aubertot J-N, 2018. Thirteen decades of antimicrobial copper compounds applied in agriculture. A review. Agronomy for Sustainable Development 38, 28, https://doi.org/10.1007/s13593-018-0503-9.

Lang G, Sage L, Wilkinson T, 2016. Ten years of studies on systems to modify sweet cherry production environments: retractable roofs, high tunnels, and rain-shelters. Acta Horticulturae 1130, 83-90, https://doi.org/10.17660/ActaHortic.2016.1130.12.

Liu X, Han R, Wang Y, Li X, Zhang M, Yan Y, 2014. Fungicidal activity of a medium-chain fatty acids mixture comprising caprylic, pelargonic and capric acids. Plant Pathology Journal (Faisalabad) 13, 65-70.

Mesnage R, Straw EA, Antoniou MN, et al., 2021. Improving pesticide-use data for the EU. Nature Ecology \& Evolution, https://doi.org/10.1038/s41559-021-01574-1.

Nuijten E, de Wit J, Janmaat L, Schmitt A, Tamm L, Lammerts van Bueren ET, 2018. Understanding obstacles and opportunities for successful market introduction of crop varieties with resistance against major diseases. Organic Agriculture 8, 285-99, https://doi.org/10.1007/s13165-017-0192-8.

OECD, 2014. Guidance document on regulatory incentives for the registration of pesticide minor uses.

Ohara T, Ishida Y, Kudou R, Kakibuchi K, Akimitsu K, Izumori K, 2008. Plant disease control agent comprising $\mathrm{D}$-tagatose as active ingredient, and plant disease control method. In: University TK, ed.

Panagos P, Ballabio C, Lugato E, et al., 2018. Potential sources of anthropogenic copper inputs to European agricultural soils. Sustainability 10, 2380, https://doi.org/10.3390/su10072380.

Research Insitute of Organic Agriculture FiBL, 2021. https://www.inputs.eu/.

Rousseau J, Chanfreau S, Bontemps É, 2013. Les Cépages Résistants and Maladies Cryptogamiques. Bordeaux, France: Groupe ICV.

Sabatino L, Scarangella M, Lazzaro F, et al., 2015. Matrine and oxymatrine in corroborant plant extracts and fertilizers: HPLC/MS-MS method development and single-laboratory validation. Journal of Environmental Science and Health, Part B 50, 862-70, https://doi.org/10.1080/03601234.2015.1062656.

Scherf A, Treutwein J, Kleeberg H, Schmitt A, 2012. Efficacy of leaf extract fractions of Glycyrrhiza glabra L. against downy mildew of cucumber (Pseudoperonospora cubensis). Eur. J. Plant Pathol. 134, 755-62, https://doi.org/10.1007/s10658-012-0051-0.

Speiser B, Mieves E, Tamm L, 2015. Kupfereinsatz von Schweizer Biobauern in verschiedenen Kulturen. Agrarforschung Schweiz 6, 160-5.

Speiser B, Schärer H-J, Tamm L, 2018. Direct plant protection in organic farming. In. Improving organic crop cultivation. Burleigh Dodds Science Publishing, 1-21.

Tamm L, Häseli A, Fuchs JG, Weibel FP, Wyss E, 2004. Organic fruit production in humid climates of Europe: Bottlenecks and new approaches in disease and pest control. Acta Horticulturae 638, 333-9, https://doi.org/10.17660/ActaHortic.2004.638.44.

Tamm L, Speiser B, Niggli U, 2018. Reduktion von Pflanzenschutzmitteln in der Schweiz: Beitrag des Biolandbaus. Agrarforschung Schweiz 9, 52-9.

Thuerig B, James EE, Schärer H-J, et al., 2018. Reducing copper use in the environment: The use of larixol and larixyl acetate to treat downy mildew caused by Plasmopara viticola in viticulture. Pest Management Science 74, 477-88, https://doi.org/10.1002/ps.4733.

Thuerig B, Tamm L, 2020. Development of plant-derived compounds as biopesticides. In: Birch $\mathrm{N}$, Glare T, eds. Biopesticides for sustainalbe agriculture. Cambridge, UK: Burleigh Dodds Science Publishing, 315-34.

van Aubel G, Buonatesta R, Van Cutsem P, 2014. COS-OGA: a novel oligosaccharidic elicitor that protects grapes and cucumbers against powdery mildew. Crop Protection 65, 129-37, https://doi.org/10.1016/j.cropro.2014.07.015. 
Willer H, Lernoud J, 2019. The world of organic agriculture. Statistics and emerging trends 2019. Research Institute of Organic Agriculture FiBL and IFOAM Organics International.

Wöhner T, Emeriewen OF, 2019. Apple blotch disease (Marssonina coronaria (Ellis \& Davis) Davis)-review and research prospects. European Journal of Plant Pathology 153, 657-69, https://doi.org/10.1007/s10658-018-1590-9.

Zhao Y, Li P, Huang K, Wang Y, Hu H, Sun Y, 2013. Control of postharvest soft rot caused by Erwinia carotovora of vegetables by a strain of Bacillus amyloliquefaciens and its potential modes of action. World Journal of Microbiology and Biotechnology 29, 411-20, https://doi.org/10.1007/s11274-012-1193-0 